\title{
Model of Ict Goods Inventory Clustering Application Using K-Means Method
}

Dahlan Abdullah, Department of Informatics, Universitas Malikussaleh, Aceh, Indonesia, dahlan@unimal.ac.id Cut Ita Erliana, Department of Industrial Engineering, Universitas Malikussaleh, Aceh, Indonesia, cutitha@unimal.ac.id

\begin{abstract}
Inventory of goods is a list that contains all the items belonging to the office. This study aims to produce an inventory clustering application that applies the k-means method to the application. The research site was conducted at the ICT PT PERTAMINA EP ASSET 1 PANGKALAN SUSU FIELD. In this study using the k-means method, which classifies goods data for the last 3 years starting from 2017, 2018 and 2019. This application was built using flowcharts, dfd, and erd. The results of the k-means calculation show that PC \& Laptop 2017, PC \& Laptop 2019, and cctv 2018 are members of C2 while C1 members are PC \& Laptop 2018, Radio HT 2017, Radio HT 2018, Radio HT 2019, Printer 2017, Printer 2018, Printer 2019, CCTV 2017, and CCTV 2019. The conclusion of this study by applying the k-means method, the calculation stops at the second iteration and can produce a clustering application.
\end{abstract}

Keywords: Application, Clustering, Inventory of Goods, ICT, K-Means.

Received: 17.11.2020 Accepted: 15.12.2020 $\quad$ Published: 03.01.2021

\section{INTRODUCTION}

The information system is a virtual system that allows management to control the company's physical system. Information systems are very much needed at this time to improve supervision of a job so that it is easier to carry out monitoring. An information system greatly affects the progress of performance because through an established information system it can provide reliable information and accelerate data access, especially in this very advanced era. Technological developments require the existence of an information system as a means of information (Mcloed and George, 2008).

Advances in computer and information technology have had a considerable influence on the performance of data processing and information presentation. Filling data manually is very troublesome and time-consuming and inaccurate data storage, so using a website-based information system can present data accurately and can facilitate work in a short time (Oktavianto, 2016).

Goods inventory is a list that contains all office items that are still in operation. Such a system will make it easier to collect and control goods. Every item collection activity will be easier if it can be controlled anywhere (Siregar, 2018).

Lots of inventory data, requires appropriate data management to present a more accurate data. The method used to divide the data into groups based on the similarities that have been previously determined is clustering. In the clustering method, objects will be grouped into one or more clusters so that the objects in one cluster will have high similarities with one another (Metisen, et, al., 2015).

K-Means is a distance based clustering method which divides data into a number of clusters and this algorithm only works on numerical attributes. The K-Means algorithm includes partitioning clustering that separates the data into separate sub-regions. The K-Means algorithm is well known for its ease and ability to cluster large data and outlier data very quickly (Metisen, et, al., 2015).

Inventory data collection carried out at ICT PT. Pertamina EP Asset 1 Pangkalan Susu Field is currently still being done manually. Officers are still using the excel application to record incoming and outgoing goods. Manual data collection in this way takes a long time when officers collect and monitor data. The large number of requests for goods that enter every year makes it difficult for ICT officers to classify goods annually.

Considering the problems faced by the officers in the inventory management department, the researcher tries to create a system to carry out a more accurate and efficient work process, especially in inventory management at ICT PT. Pertamina EP Asset 1 Pangkalan Susu Field. 


\section{LITERATURE REVIEW}

Inventory is the process of managing the procurement or inventory of goods owned by an office or company in carrying out its operational activities. Without an inventory, a business activity will not be carried out, therefore the existence of an inventory is very important. Office inventory is very important for the continuity of an agency. If one or more of the equipment is damaged, it will definitely hinder the running of the economy. Companies that are usually in the form of an irregular organization of an office inventory or a lack of a system for inventorying office equipment (Andi and Wahana Komputer, 2010).

Inventory is an activity carried out to record incoming and outgoing goods and arrange them correctly in accordance with the regulations that have been applied (Siswanto and Khambali, 2018). Meanwhile, Kinaswara (2019) said that inventory is a way of recording items that are carried out to register every item owned by the office so that they can be used in carrying out each task.

According to several sources about the definition of inventory:

a. Inventory is a stock of an item or resource used in a company organization (Assauri, 2016).

b. Inventory (stock) which is all types of goods owned by a company and is used to support its business processes (Martono, 2015).

Inventories are materials or goods that are stored for certain purposes, including for the production process, if they are raw materials, they will be further processed, if they are components (spare parts), they will be sold back into merchandise (Siagian, 2005).

\section{METHOD}

This research on goods inventory application using the k-means method was conducted from July to December 2020. This research was conducted over a period of approximately 6 months.

Research on inventory application using the k-means method was conducted at ICT PT. Pertamina EP Asset 1 Pangkalan Susu Field. This location was taken because it has all the supporting aspects for the application needs to be built so that the research runs well.

Research is an attempt to test carefully and in a crisis in search of facts and principles using systematic steps. Research methods are procedures or steps in obtaining scientific or scientific knowledge. The research method is a systematic way to organize science. While the research technique is a way to carry out research methods. Research methods usually refer to forms of research. (Suryana, 2010).

The steps that the author takes in the process of making this thesis are using the waterfall method, where the first step is analysis of system requirements to system testing.

Research steps carried out are:

a. Study of literature

b. Needs Analysis

c. System planning

d. System Implementation

e. System Testing

f. Conclusion

\section{RESULT AND DISCUSSION}

In this study, the authors will implement clustering using the k-maens method into the goods inventory application considering the large number of requests for goods that enter the ICT inventory which makes it difficult for officers to group goods annually into several groups of goods. The grouping of goods that has been carried out will essentially become information for the officer to know which goods belong to which group of goods.

System analysis is the earliest stage of system development which is the foundation for determining the success of the resulting information system. System analysis has three stages in describing system development, namely: problem analysis, needs analysis, process analysis.

Every year ICT PT. PERTAMINA EP ASSET 1 PANGKALAN SUSU has a very large demand for goods, these very many items require grouping. The ICT grouping of PT. PERTAMINA EP ASSET 1 PANGKALAN SUSU still performs manual grouping every year which makes it difficult for officers to determine each year the goods fall into groups of goods which by applying the k-means method in the application of inventory of goods the results of this application can be used by ICT officers. 
In this section, we will discuss various processes from research carried out from actual data, where the system will be tested by implementing a program design design using a programming language. The design of this system starts from analyzing the needs and existing problems to finding practical solutions using computer algorithms and methods, designing processes that will be carried out later, implementing and testing the system.

In this manual calculation, the author uses the goods data starting from 2017 to 2019 as many as 24 data which have been totaled from the data of goods requested and received from 2017 to 2019.

Table 1. Item Data 2017, 2018 and 2019

\begin{tabular}{|l|l|l|}
\hline Name \& Year & Request & Reception \\
\hline PC \& Laptop 2017 & 82 & 39 \\
\hline PC \& Laptop 2018 & 54 & 33 \\
\hline PC \& Laptop 2019 & 116 & 81 \\
\hline Radio HT 2017 & 48 & 22 \\
\hline Radio HT 2018 & 46 & 25 \\
\hline Radio HT 2019 & 51 & 26 \\
\hline Printer 2017 & 40 & 23 \\
\hline Printer 2018 & 21 & 16 \\
\hline Printer 2019 & 16 & 12 \\
\hline CCTV 2017 & 70 & 36 \\
\hline CCTV 2018 & 81 & 57 \\
\hline CCTV 2019 & 53 & 38 \\
\hline
\end{tabular}

The steps for grouping goods using the k-means method are as follows:

1. Determine the number of clusters you want to specify

Determining the number of clusters you want to form is the first step. From the data that has been obtained, the cluster that you want to form into 2 clusters, namely $\mathrm{C} 1=$ is the least received data while $\mathrm{C} 2=$ is the most received data. In the data year group table for 2017, 2018 and 2019 above, we can see the data that was received the least, namely the printer data in 2018, therefore we can make the 2018 printer data C1. While the most data received, namely 2019 pc and laptop data, means that 2019 PCs and laptops are C2.

2. Determine the centroid point

The centroid point is taken from the goods data 2017, 2018, and 2019, has 2 centroid points, namely X and $\mathrm{Y}$. Where the $\mathrm{X}$ centroid point is demand, while the $\mathrm{Y}$ centroid point is acceptance. The centroid point $\mathrm{C} 1$ is taken from the least received data, while $\mathrm{C} 2$ is taken from the most received data. In the goods data table 2017,2018 , and 2019, $\mathrm{X}$ is demand, while $\mathrm{Y}$ is revenue. Centroid C1 gets the point values $\mathrm{X}=16$ and $\mathrm{Y}=12$ because centroid $\mathrm{C} 1$ is the least received 2018 printer data. At centroid $\mathrm{C} 2$, point $\mathrm{X}=116$ and $\mathrm{Y}=81$ because the C2 centroid contains data for PCs and laptops for 2019 which had 116 requests and 81 receipts.The centroid values can be seen in the table below:

\section{CONCLUSION}

The results showed that the ICT inventory clustering application used the k-means method to cluster data for the last 3 years, the three-year data that had been calculated using the cluster resulted in the following calculations:

PC \& Laptop 2017 c1 (39,956921247208) c2 (22,825424421027)

PC \& Laptop 2018 c1 $(12,133516482134)$ c2 $(46,872166581032)$

PC \& Laptop 2019 c1 $(90,542193969933)$ c2 $(31,827660925679)$

Radio HT 2017 c1 (5,185449728701) c2 (58,258046654518)

Radio HT 2018 c1 $(1,795054935712)$ c2 $(58,008620049093)$

Radio HT 2019 c1 $(6,674994798167)$ c2 $(53,413481444295)$

Printer 2017 c1 (5,088112507491) c2 (64,070273918565)

Printer 2018 c1 $(25,256462319353)$ c2 $(83,862983490930)$

Printer 2019 c1 $(31,457201966411)$ c2 $(90,210864090751)$ 
CCTV 2017 c1 $(27,668674625930)$ c2 $(32,526911934581)$

CCTV 2018 c1 $(48,230925993829)$ c2 $(12,165525060596)$

CCTV 2019 c1 $(15,073892072793)$ c2 $(45,177427992306)$

From the $\mathrm{c} 1$ and $\mathrm{c} 2$ data above, the cluster results are:

PC \& laptop 2017, PC \& laptop 2019, and cctv 2018 are members of c2 while c1 members are PC \& laptop 2018, Radio ht 2017, Radio ht 2018, Radio ht 2019, Printer 2017, Printer 2018, Printer 2019, CCTV 2017, and CCTV 2019. By implementing the k-means method for clustering, the calculation of the k-means method stops at iteration 2 .

\section{REFERENCES}

Andi. Kumpulan Aplikasi Perkantoran Online.Penerbit Wahana Komputer, 2015.

Anggraini, E.Y. dan Ira Invani. Pengantar Sistem Informasi. Penerbit Aindi. 2017.

Ardhana, Kusuma Y.M. Project HP \& Mysql Membuat Website Buku Digital. Jasakom. 2014.

Assauri, Sofyan. Manajemne Operasi Produksi Pencapaian Sasaran Organisasi Berkesinumbungan. PT. Raja Grafindo, 2016.

Bahra, A.L. Analisis dan Desain Sistem Informasi. Graha Ilmu, 2013.

Enterprise. Pemrograman Bootsrap Untuk Pemula, Penerbit Erlangga, 2016.

Enterprise. HTML \& CSS. Penerbit erlangga, 2016.

Fatta, H.A. Analisis dan Perancangan Sistem Informasi Untuk Keunggulan Bersaing Perusahaan dan Organisasi Modern. 2007.

Faizal, Edi dan Irnawati. Pemrograman java web (JSP, JSTL \& SERVELET) tentang pebuatan sistem informasi klinik diimplementasikan dengan net beans IDE7.2 dan MySQL. Grava Media. 2015.

Khambali, Ahmad dan Agus Siswanto. Sistem Informasi Inventaris Alat dan Barang Berbasis Web Paa SMA Kandangeroan. Jurnal Surya Informatika.5.1(2018).

Kinaswara, T.A., Nasrol R.H. dan Fatima Nugratanti. Cadangan Bangun Aplikasi Inventaris Berbasis Website Pada Kelurahan Bantengan. Seminar Nasional Teknologi Informasi \& komunikasi (2019).

Madcoms. Pemrograman PHP dan MYSQL untuk Pemula. Penerbit Erlangga, 2016.

Martono, Ricky. Manajemen Logistik Terintegrai. PPM, 2015

Mcloed, K dan George P.S. Sistem Informasi Manajemen; edisi 10.Penerbit Salemba, 2008.

Marudut, Victor Mulia Siregar. Perancangan Sistem Informasi Inventaris Barang Pada Sekolah SMA Negeri 4 Pematang Siantar. IT Journal Research and Development.3.1 (2018).

Metisen, M.B., Herlina dan Latipa Sari. Analisis Clustering Menggunakan Metode K-Means Dalam Pengelompokkan Penjualan Produk Pada Swalayan Fadhila. Jurnal Media Infotama.11.2 (2015).

Munawaroh, Siti. Peancangan Sistem Informasi Persediaan Barang. Jurnal Teknologi Informasi Dinamik. 9.2(2006).

Muningsih, Elly dan Sri Wiswati. Penerapan Metode K-means Untuk ClusteringProduk Online Shop dalam Penentuan Stok Barang. Bianglala Informatika. 3.1(2015).

Nasari, Fina dan Surya Darma. Penerapan K-means Clustering Pada Data Penerimaan Mahasiswa Baru. Seminar Nasional Teknologi Informasi \& Multimedia (2015).

Nugroho, Database Relational dengan MYSQAL. Penerbit Erlangga, 2007.

Nugroho, Bunafit. Pemrograman Web: Memuat Sistem Informasi Akademik Sekolah dengan PHP, MySQL dan Dreamweaver. Gava Media, 2014.

Oktavianto, M.M. Analisis dan Perancangan Sistem Informasi Menggunakan Model Terstruktur dan UML, Penerbit Andi. 2016.

Patma, T.S., M. Maskan dan Alifulahtin utaminigsih. Sistem Informasi Manajemen Guna mendukung Keputusan, Penerbit Andi, 2016.

Pressman, Roger S. Rekayasa Perangkat Lunak Praktisi Edisi 7. Penerbit Andi, 2010.

Raharjo, Budi. Belajar Otodidak MySQL, Teknik Pembuatan dan Pengelolaan Database. Informatika. 2010.

Rosa, A.S dan Salahuddin, M. Rekayasa Perangkat Lunak Terstruktur dan Beroientasi Objek. Informatika. 2014.

Santoso, Harip. Membuat Multiaplikasi Menggunakan Visual Basic, PT. Elex Media Komputindo, 2005.

Siagiana, Y.M. Supply Chain Management dalam Dunia Bisnis. PT. Grasindo. 2005.

Sianipar, Siahaan. Javascript Untuk Profesional. Wahana Komputer, 2018.

Suryana, Dayat. Sistem Informasi Pengajian Karyawan. PT. Grasindu. 2010. 
Sutabri, T. Konsep Sistem Informasi. Penerbit Andi. 2012.

Suyanto, M. Pengantar Teknologi Informasi Untuk Bisnis. CV Andi Offset.

Tim EMS. All in One Web Programming, Pemrograman Web dengan HTML, PHP, AJAX, dan Jawery Mobile, PT. Elex Media Komputindo. 2016.

Wahyudi, M., Masitha, Risna Saragih dan Solikhun. Data Mining : Penerapan Algoritma K-means Clustering dan K-means medoids clustering. Yayasan Kita Menulis, 2020.

Wicaksosno, A.Y., Ridwan Rismanto dan Arief prasetya. Pengembangan Aplikasi Sistem Informasi Rekomendasi Tempat Wisata di Kota Batu Menggunakan Metode Electre. Jurnal Informatika Wolinema. 3.2 (2017). 